\title{
A CASE OF MYXOEDEMA COMA SUCCESSFULLY TREATED WITH TRI-IODO-THYRONINE
}

\author{
By S. J. SuRTEes, M.B.(L'pool) \\ and S. GinsBeRg, M.B.(Birm.) \\ Medical Registrars, Walton Hospital, Liverpool
}

\section{Introduction}

The termination of myxoedema in coma was described in the Report of the Clinical Society of London (1888) and had been noted even before this (St. Thomas's Hospital Report, 1879). It is an uncommon complication occurring in longstanding untreated cases and hitherto was fatal, with the possible exception of one patient (Malden, 1955), and here the cerebro-spinal fluid protein was markedly raised and on recovery there was a unilateral hypereflexia suggesting a cerebrovascular accident complicating myxoedema.

This article reports the successful treatment of an undoubted case of myxoedema coma with oral tri-iodo-thyronine.

\section{Case Report}

Mrs. E. A., aged 69, was admitted to Walton Hospital at 8.30 p.m. on January 22 , 1957, as a case of 'apoplexy.' The casualty officer noted that she was unconscious.

The relatives said that she had felt the cold excessively for many years and her face had become puffy over the last 12 months. For six months she had restricted her activities and been troubled with deafness. During the previous week she was drowsy, had taken to sleeping during the afternoon, and on the day of admission was found to be unrousable in her chair.

The patient had had three normal deliveries, the last 25 years ago, and had menstruated again after the last pregnancy.

On examination the patient was comatose. She had a typical myxoedematous facies, the skin was cold and dry, the axillae were dry and hairless, the vulval hair was absent and the labial hair sparse. She could not talk, but was capable of making croaking noises on painful stimulation.

The pulse rate was 52 per minute and regular, the blood pressure $180 / 100$, and the heart sounds very distant. There was no evidence of neurological abnormality apart from absent ankle jerks, but the ocular fundi could not be adequately
A Case of Ifycoedema Coma Successfully Treated with Tri-1odo-thyronine. 12.

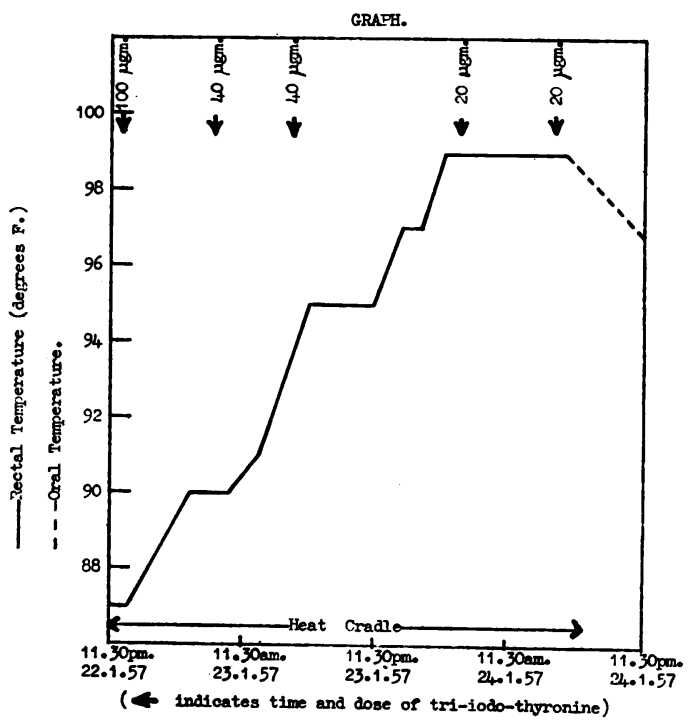

visualized due to bilateral lenticular opacities. The rectal temperature was $87^{\circ} \mathrm{F}$. (after ten minutes' insertion of a laboratory thermometer).

The investigations performed on admission are tabulated.

\section{Treatment}

The patient was put in a heat cradle and at midnight rooug. of $3-5-3^{\prime}-1$-tri-iodo-thyronine was given intragastrically by means of a Ryles tube.

On the morning of January 23. her conscious level was higher in that spontaneous movements were more frequent, but she was still not talking although the rectal temperature had risen (see graph). She was given $40 \mu \mathrm{g}$. of tri-iodothyronine by the same route at Io a.m. During the day she became more active, the pulse rate rose to 68 per minute and the rectal temperature to $95^{\circ} \mathrm{F}$. She was given a further $40 \mu \mathrm{g}$. of tri- 
i 7-Ketosteroid Estimation by the Method of MoXham and Nabarro, 1956

\begin{tabular}{|c|c|c|c|c|c|c|}
\hline & January 22 & January 23 & January 24 & January 29 & February 5 & February 14 \\
\hline $\begin{array}{l}\text { Serum cholesterol (mg./\%) } \\
\text { Blood sugar }(\mathrm{mg} . / \%) \\
\text { Serum potassium }(\mathrm{mEq} / 1 .)\end{array}$ & $\begin{array}{c}645 \\
122 \\
4.9 \\
126 \\
95\end{array}$ & $\begin{array}{c}4.7 \\
122 \\
94 \\
\\
\\
65 \\
82 \\
4,300 \\
\end{array}$ & $\begin{array}{c}565 \\
4.9 \\
120 \\
93 \\
3.1 \\
\\
2.8\end{array}$ & 445 & $\begin{array}{l}7.0 \\
\text { I } 3.6\end{array}$ & $\begin{array}{c}75 \\
9,100\end{array}$ \\
\hline
\end{tabular}

iodo-thyronine administered in a milk drip commencing at 6 p.m.

The next day (January 24) she could just speak a few words and she was slowly returning to a normal conscious level. The pulse rate was 88 per minute and the rectal temperature $99^{\circ} \mathrm{F}$. She was put on $40 \mu \mathrm{g}$. of tri-iodo-thyronine daily by mouth.

At i I.30 p.m. on January 25 she had become very restless and was singing in the ward. It was considered that she had become mentally hyperactive following tri-iodo-thyronine therapy and she was sedated with paraldehyde $5 \mathrm{ml}$. I.M. and the tri-iodo-thyronine suspended until January 27 (when she was started on $20 \mu \mathrm{g}$. daily), by which time although still slightly confused and noisy she was more rational.

Over the next two days she made a remarkable recovery, becoming quite rational and able to walk about the ward. Now that she was cooperative a B.M.R. was performed (February 2) and gave a result of minus 25 per cent. An E.E.G. (February 6) was reported by Dr. E. A. Nieman as " there is a well-developed regular 8 per second alpha rhythm and some slow activity within the theta range,' a picture found in cases of myxoedema. Chext X-ray showed no pulmonary pathology and the heart size was within normal limits.

On February 13 she complained of vomiting and admitted to having not felt well the previous day, but she denied any chest pain. Examination showed her to be in mild congestive heart failure. She was put to bed, digitalized, given mercurial diuretics, a salt-free diet and the tri-iodo-thyronine was discontinued. By February $\mathbf{I} 6$ her vomiting had settled, the heart failure improved and she was given cortisone $25 \mathrm{mg}$. twice daily (because the possibility of a hypopituitary state was entertained) and the tri-iodo-thyronine in a dose of $20 \mu \mathrm{g}$. daily recommenced.

On February 18 she complained of palpitations and breathlessness, the pulse rose to i Io per minute, the blood pressure fell to iro/60 (the rectal temperature was $97.4^{\circ}$ F.), and she was found to be in severe congestive heart failure. She collapsed shortly afterwards and died.

\section{Post Mortem}

There was oedema of the ankles and about $200 \mathrm{ml}$. of clear fluid was found in both pleural cavities. The lungs, liver and spleen were congested, but otherwise of normal appearance. There was severe atheroma of the coronary arteries and the right coronary artery contained atheromatous debris on which was superimposed a recent (still red) thrombus for a distance of $2 \mathrm{~cm}$. The myocardium of the posterior wall of the left ventricle and of part of the septum showed a diffuse exten $\mathscr{\ell}$ sive infarction. 'There was very advanced athers oma of the aorta and the mesenteric arteries. The uterus and ovaries appeared normal for her age?

On histological examination the thyroid was very small and weighed $3.8 \mathrm{~g}$. It consisted practically entirely of fibrous tissue in which only occasional tiny islets of atrophic thyroid tissue were found.

The adrenals were of normal size (5.8 and $6.2 \mathrm{~g}$.). The cortex contained only a moderate amount of lipoid. The zona reticulata appeared slightly atrophic; there were a number of small hyperplastic nodules in the zona glomerulosa. The adrenal medulla contained numerous large Russel bodies and some of the medullary cells in the vicinity had very large nuclei.

The pituitary weighed I g. The general structure was normal, but many of the basophil cells contained small vacuoles. The proportion of the different types of cells was normal. The pancreas appeared normal and healthy on naked-eye and microscopic examination. Both ovaries showed senile atrophy with no trace of ova. Only one parathyroid was found. This showed normal histological appearances and had the usual islets of eosinophil cells.

\section{Discussion}

This was a case of primary myxoedema which 
had progressed to the stage of hypothermic coma and the post-mortem findings were in accord with the clinical diagnosis, showing no evidence of preceding adrenal or pituitary abnormality.

The depression of adreno-cortical function as demonstrated by the 17 ketosteroids and 17 ketogenic steroids estimation on January 25 is a secondary effect (Statland and Lerman, 1950). It is generally accepted that adrenal cortex failure follows thyroid function failure (Hill, Reiss, Forsham and Thorn, 1950; Hubble, 1955) and the rapid elevation to normal levels of this patient's corticoid excretion after substitution therapy would tend to confirm this view and might also suggest that tri-iodo-thyronine is more active than thyroid sicca in restoring adrenal function. The normal serum electrolytes and blood glucose in this case emphasizes that the adrenal hypofunction was minimal; although electrolyte imbalance has been recorded in some cases of myxoedema coma (Summers, 1953; Le Marquand, Hausmann and Hemsted, I953; Curtis, I956), treatment with cortisone, thyroxine and heat did not produce a satisfactory response.

The many features of similarity in the clinical pictures of hypopituitary and myxoedema coma may lead to some difficulty in differentiation. In hypopituitary coma there is often a history of severe post-partum haemorrhage followed by amenorrhoea and loss of libido and the ictus is generally preceded by infection or trauma (Caughey and Garrod, 1954). It can also be classified into several relatively well-defined types, namely, hypoglycaemic, hypothermic or electrolyte imbalance/water retaining (Sheehan and Summers, 1952), and the treatment is to correct the pertinent abnormality.

The almost constant finding of hypothermia in myxoedema coma would suggest the application of heat to the patient. A heat cradle was used in this instance, but it has been shown that the elevation of body temperature in itself is insufficient to produce recovery, in contradistinction to its successful use in hypothermic hypopituitary coma (Sheehan and Summers, 1952). It is interesting to note that a case of myxoedema coma has been described in which the patient was febrile (Karhausen and Zylberszac, 1955).

Experience with 3-5-3'-1-tri-iodo-thyronine has demonstrated its potency in myxoedema (Gross, Pitt-Rivers and Trotter, 1952; Asper, Selenkow and Plamondon, I953; Deltour and Bekaert, 1953; Lerman, 1954) and shown that whereas its short duration of action precludes routine use in hypothyroid patients (Frawley, McClintock, Beebe and Marthy, 1956), its rapidity of action makes it the logical therapy in myxoedema coma. $1,000 \mu \mathrm{g}$. of tri-iodo-thyronine given intravenously to a case of myxoedema (Rawson et al., I953) was shown to raise the B.M.R. appreciably in seven hours and to exert its maximal effect in 24 hours, whereas 1-thyroxine in a dose of $3 \mathrm{mg}$. I.V. produced a slight rise in the B.M.R. in 24 hours and a maximal effect in I I days. A comparable rapidity in action has been noted with oral administration (Zondek, Leszynsky and Zondek, 1955).

Two reports of its use in myxoedema coma have appeared in this country and in both cases, despite some improvement, the patient died before attaining a euthyroid state (Dyson and Wood, 1956; Anderson and Hausmann, 1956). However, the efficacy of tri-iodo-thyronine in this condition has been amply shown by the response in this case. It is quite possible that either larger dosages or the use of the intravenous route may produce serious cardiac complications (Frawley et al., 1956), such as auricular fibrillation, angina and congestive heart failure. In this case the cause of death was due to a coronary thrombosis and tri-iodo-thyronine therapy was not considered a contributory factor as the patient had been euthyroid on a maintenance dose of $20 \mu \mathrm{g}$. daily for a period of two weeks and post mortem demonstrated a recent thrombosis and infarct. E.C.G.s performed on January 23 and 24 showed a tendency to low complexes although by no means displaying a typical myxoedema record (but the patient had been on treatment for 12 and 36 hours respectively). A repeat record on February I4 showed changes suggestive of lateral infarction and sub-endocardial ischaemia.

In conclusion, it is suggested that cases of myxoedema coma be given tri-iodo-thyronine intragastrically and in relatively small doses. The use of heat may be beneficial. On the rare occasions when there is severe associated endocrine hypofunction as evidenced by electrolyte disturbance or hypoglycaemia the use of cortisone and intravenous glucose and saline would appear to be logical.

\section{Summary}

I. A case of myxoedema coma successfully treated with oral tri-iodo-thyronine is described.

2. The question of associated endocrine disturbance is discussed.

3. A regime of treatment for future cases is suggested.

\section{Acknowledgments}

We wish to thank Dr. M. J. J. Wodzinski who performed the post mortem, Prof. H. L. Sheehan for the histological report, and Dr. V. K. Summers for his helpful advice and criticism.

Bibliography continued on page 449. 
Spontaneous Intra-Gastric Rupture of a Pscudocyst of Pancreas-E. T. Murray, F.R.C.S.

\section{BIBLIOGRAPHY}

BRUNSCHWI(;, A. (I942), 'Surgery of Pancreatic 'Iumours,' St. Louis: Mosby Co.

CAT'TELL, R. B., and WARREN, K. W. (1953), 'Surgery of the Pancreas,' Philadelphia: Saunders.

DOUBILE'T, H., and MULHOLLANI), J. H. (1953), Surg. Gynec. Obstet., 96, 683 .

(jULEKE, N. (1912), Ergebn. Chir. Orthop., 4, 408.

GUSSENBAUER, C. (1882), Arch. klin. ( hir., 29, 355.

HAHN, O. ( (1927), Zbl. Chir., 54, 585.

JUDD, E. S., MAT'TSON, H., and MAHORNER, HI. R. (193I), Arch. Surg. (( 'hicago), 22, 838 .
JURAS', A. (1931), Arch. klin. Chir., 164, 272. KERSCHNER, F. (1929), Beitr. Klin. Chir., 147, 28. KOR'TE, W. ( 1911 ), Dtsch. med. Wschr., 37, 536.

KUNC, Z. (1947), F. int. ('oll. Surg., 10, 529.

MAHORNER, H. R., and MAT'TSON, H. (1931), Arch. Surg., 22, 1018 .

MEYER, K. A., SHERIDAN, A. I., and MURPHY, R. F. (1949), Surg. Gynec. Obstet., 88, 219.

NEUFFER, H. (1932), Arch. klin. ('hir., 170, 488.

POPPELL, M. H. (1951), 'Roentgen Manifestations of Pancreatic Disease,' Illinois: Charles C. 'Thomas.

ROSSING; H. G. (1942), Zbl. Chir., 69, I671.

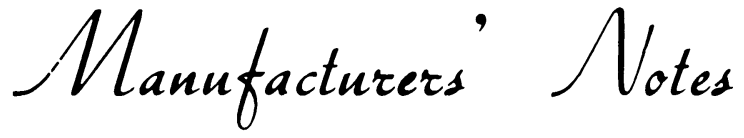

Pharmaceutical Specialities (May \& Baker) Ltd. announce the introduction of two new presentations of 'Stemetil' brand prochlorperazine for use in psychotic illnesses. 'These are tablets of $25 \mathrm{mg}$. of the dimaleate, and 2 c.c. ampoules of $1.25 \% \mathrm{w} / \mathrm{v}$ solution of the methanesulphonate.

Clinical trials of prochlorperazine in psychoses have been in progress in mental hospitals in the United Kingdom and abroad for more than two years. Evidence from these widespread studies, some of which are still in progress, has indicated that prochlorperazine is a valuable addition to those drugs already available for the management of psychotic illnesses.

'The primary indication of 'Stemetil' is in the management of schizophrenia. In many cases 'Stemetil' may make withdrawn, autistic, catatonic cases amenable to psychotherapy at a relatively early stage in treatment. It may be employed successfully in the management of excitement whether associated with schizophrenia, the manic-depressive psychosis, or other psychiatric conditions wherein agitation and excitement are notable features. Although the drug has been used on a very large number of patients, no case of jaundice or blood dyscrasia attributable to its use has been reported.

\section{' DISTAQUAINE' V-K 125 \\ Bottle of 1,000 tablets}

The Distillers Company (Biochemicals) Limited announces the availability of a new pack of 'Distaquaine' V-K 125 tablets of potassium penicillin V. Each tablet contains the equivalent of I $25 \mathrm{mg}$. penicillin $\mathrm{V}$ free acid (as potassium salt).

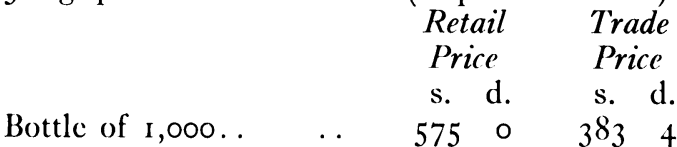

\section{DQV-K 250}

'The I)istillers Company (Biochemicals) Limited announces the availability of 'Distaquaine' $\mathrm{V}-\mathrm{K}$ 250 tablets. Each scored tablet contains the equivalent of $250 \mathrm{mg}$. penicillin $\mathrm{V}$ free acid (as potassium salt). Packs and prices are as follows:-

Retail Trade

Price Price

Bottle of 100 ..

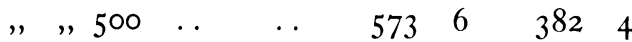

Bibliography contimued from page 445-S. F. Surtees, M.B., and S. Ginsberg, M.B.

\section{BIBLIOGRAPHY}

ANDERSON, $\Lambda$. , and HAUSMANN, W. (1956), Lancet, ii, 990. ASPER, S. P., SELENKOW, H. $\Lambda$. , and PLAMONDON, C. $\Lambda$. (1953), Bull. Fohns Hopk. Hosp., 93, 164.

CAUGHEY, J. E., and GARROD, O. (1954), Brit.med. F., ii, 554. CURTIS, R. H. (1956), Ann. intern. Med., 44, 376.

DELTOUR, G., and BEKAERT, J. (1953), Ann. Endocr. (Paris), I4, 87.

DYSON, A., and WOOD, M. W. W. (1956), Lancet, ii, 757.

FRAWLEY, T. F., McCLINTOCK, J. C., BEEBE, R. 'T., and MARTHY, G. L. (1956), F. Amer. med. Ass., 16o, 646

(iROSS, J., PITT-RIVERS, R., and 'TRO'TTER, W. R. (1952), Lancet, $\mathrm{i}$, 1044 .

HILL, S. R., REISS, R. S., FORSHAM, P. H., and THORN, G. W. (1950), $\mathcal{F}$. clin. Endocr., 10, 1375 .

IIUBBLE, D. (1955), Lancet, i, I.
KARHAUSEN, L., and ZYLBERSZAC, s. (I955), Brit. med. F., ii, 766 .

LE MARQUAND, H. S., HAUSMANN, W., and HEMSTED, E. H. (1953), Ibid., i, 704 .

LERMAN, J. (1954), f. clin. Endocr., 13, 1341.

MALDON, M. (1955), Brit. med. $\mathcal{F}$., ii, 764 .

RAWSON, R. W., RALL, J. E., PEARSON, O. H., ROBBINS, J., POPPELL, H. F., and WEST, C. D. (1953), Amer. F. med. Sci., 226, 405 . SHEEHAN, H. L., and SUMMERS, V. K. (1952), Brit. med. F.,

STATLAND, H., and LERMAN, J. (1950), f. clin. Endocr., ro I $40 \mathrm{I}$.

SUMMERS, V. K. (1953), Brit. med. F., ii, 366.

ZONDEK, H., LESZYNSKY, H. E., and ZONDEK, G. W. (I955), Acta endocr. (Kbh), 18, 117. 